\title{
Human Monoclonal Autoantibodies that React with Both Pancreatic Islets and Thyroid
}

\author{
Carlo Garzelli, * Floyd E. Taub," Mark C. Jenkins," Daniel W. Drell," Fredda Ginsberg-Felliner,‡ and Abner Louis Notkins* \\ Laboratory of Oral Medicine,* National Institute of Dental Research, National Institutes of Health, \\ Bethesda, Maryland 20892; and Division of Pediatric Endocrinology \\ and Metabolism, $\ddagger$ Department of Pediatrics, Mount Sinai School of Medicine, New York 10029
}

\begin{abstract}
Transformation of human peripheral blood lymphocytes with Epstein-Barr virus and rapid screening on rat insulinoma cells by an enzyme-linked immunosorbent assay were used to identify monoclonal autoantibodies that reacted with human pancreatic islets. Six such monoclonal autoantibodies were isolated and cloned. All six also were found to react with human thyroid. It is concluded that lymphocytes able to make autoantibodies that react with both the pancreas and thyroid are common in the human B cell repertoire.
\end{abstract}

\section{Introduction}

Antibodies that react with pancreatic islets are frequently found in the serum of patients with newly diagnosed insulin-dependent diabetes mellitus (IDDM) ${ }^{1}(1-3)$. What is perhaps not as fully appreciated is that autoantibodies that react with a variety of other organs (e.g., gastric mucosa, adrenals, anterior pituitary, lymphocytes) are also found in the serum of IDDM patients (47). Autoantibodies that react with the thyroid are particularly common (8-11). The nature of this multiple organ autoreactivity of serum has never been fully explained. There are at least two possibilities. One is that the serum of IDDM patients contains a number of organ-specific antibodies. The second is that the serum contains antibodies that recognize common proteins or epitopes in different organs. Using hybridoma technology or Epstein-Barr virus (EBV) transformation, it is now becoming possible to address this question by studying the reactivity of human monoclonal autoantibodies (12-14). In this paper, we describe a simple and rapid screening procedure for detecting human monoclonal autoantibodies that react with pancreatic islets, and show that many of these antibodies also react with the thyroid and other human tissues.

\section{Methods}

Patients. Peripheral blood lymphocytes (PBL) were obtained from 10 patients: four with IDDM, five with both diabetes and thyroiditis, and one with hyperthyroidism but no diabetes. The six EBV-transformed

\section{Address correspondence to Dr. Notkins. \\ Received for publication 18 June 1985 and in revised form $18 \mathrm{No}$ vember 1985 .}

1. Abbreviations used in this paper: $\mathrm{ABC}$, avidin-biotin complexes; $\mathrm{EBV}$, Epstein-Barr virus; ELISA, enzyme-linked immunosorbent assay; IDDM, insulin-dependent diabetes mellitus; LSM, lymphocyte separation medium.

The Journal of Clinical Investigation, Inc.

Volume 77, May 1986, 1627-1631 cell lines reported herein were derived from five of these patients: three males and two females; mean age, $10.4 \mathrm{yr}$; mean duration of diabetes, $3.0 \mathrm{yr}$. Two cell lines were derived from one of the patients with diabetes; one cell line each was derived from three of the patients with diabetes and thyroiditis, and one cell line was derived from the patient with hyperthyroidism.

Preparation of $E B V$. EBV was obtained from the culture supernatant of the B95-8 marmoset cell line (15). B95-8 cells were cultured at $37^{\circ} \mathrm{C}$ in RPMI 1640 supplemented with 10\% fetal bovine serum (Flow Laboratories, McLean, VA), $2 \mathrm{mM}$ L-glutamine, and antibiotics (culture medium). For virus production, the cells were cultured at a concentration of $10^{6} / \mathrm{ml}$ and incubated for $10 \mathrm{~d}$ at $34^{\circ} \mathrm{C}$. The virus-containing supernatant was removed, filtered through a $0.45-\mu \mathrm{m}$ millipore filter, and stored at $-70^{\circ} \mathrm{C}$.

Establishment of lymphoblastoid cell lines by EBV transformation. Human PBL were isolated from $20 \mathrm{ml}$ of heparinized blood by centrifugation on lymphocyte separation medium (LSM; Bionetics Laboratory Products, Charleston, SC), washed three times, and then separated into $T$ and B lymphocyte-enriched populations over a nylon wool column (16). $5 \times 10^{6} \mathrm{~B}$ lymphocytes were suspended in $1 \mathrm{ml}$ of culture medium, mixed with $0.5 \mathrm{ml}$ of B95-8 cell line supernatant, incubated for $2 \mathrm{~h}$ at $37^{\circ} \mathrm{C}$, and then washed once with culture medium. $5 \times 10^{4} \mathrm{~B}$ lymphocytes infected with EBV and $1 \times 10^{5} \mathrm{~T}$-enriched autologous cells treated with mitomycin $\mathrm{C}\left(25 \mu \mathrm{g} / \mathrm{ml}, 20 \mathrm{~min}, 37^{\circ} \mathrm{C}\right)$ were then seeded in $0.2 \mathrm{ml}$ of culture medium in wells of a 96-well plate (3596; Costar, Cambridge, MA). The plates were placed in a humidified atmosphere in the presence of $7.5 \% \mathrm{CO}_{2}$. The cells were fed twice weekly by replacing half of the culture medium with fresh medium. The occurrence of cell transformation was judged by cell aggregation, acid production, increase in cell number, and acquisition of the ability to be successfully subcultured (15). The production of immunoglobulin, its class and concentration were determined by an enzyme-linked immunosorbent assay (ELISA) (13).

Screening for antibodies. Confluent microcultures of rat insulinoma cells (RIN 5F) (17) were grown in 96-well plates, washed three times with phosphate-buffered saline (PBS), and then fixed with $0.5 \%$ glutaraldehyde in PBS for $5 \mathrm{~min}$ at room temperature. The fixed cells were washed once, incubated for $5 \mathrm{~min}$ at room temperature in $0.15 \mathrm{M}$ glycine in PBS, and then washed two more times before storage in PBS at $4^{\circ} \mathrm{C}$. The fixed RIN $5 F$ cells were used within $3 \mathrm{~d}$.

To detect antibodies in the culture supernatants of EBV-transformed cells, fixed RIN 5F cells were washed three times in PBS containing 0.05\% Tween 20 (Sigma Chemical Co., St. Louis, MO) (PBS-Tween), and incubated with $100-\mu l$ aliquots of the culture supernatants diluted 1:3 in PBS-Tween. A human monoclonal IgM (MOR-h1) reacting with islets (12) served as a positive control and a nontissue reacting human monoclonal IgM, designated 69-1A-33, served as the negative control. After 1-h incubation at $37^{\circ} \mathrm{C}$, the cells were washed three times with PBS-Tween and then incubated at room temperature for $1 \mathrm{~h}$ with 100 $\mu l$ of a 1:400 dilution of goat anti-human IgM, or a goat anti-human IgG, conjugated to peroxidase (Cappel Laboratories, Malvern, PA). After three additional washes, the plates were developed with $0.01 \% \mathrm{H}_{2} \mathrm{O}_{2}$ and $0.01 \%$ o-phenylenediamine (Sigma Chemical Co.). The optical density at $492 \mathrm{~nm}$ was read using a Multiscan Microplate reader (Flow Laboratories). Wells with optical readings greater than three standard deviations above the mean of the negative controls were scored as positive for antibody activity. 
Table I. Reactivity of EBV-induced Human Monoclonal Antibodies with RIN $5 F$ Rat Insulinoma Cells

\begin{tabular}{lll}
\hline Monoclonal antibody & Ig class* & Binding to fixed RIN SF cellsł \\
\hline & & $c p m$ \\
Culture medium & - & $149 \pm 41$ \\
69-1A-33 (Negative control)§ & $\operatorname{IgM}(\kappa)$ & $194 \pm 38$ \\
Mor-h1 (Positive control)§ & $\operatorname{IgM}(\kappa)$ & $1,589 \pm 242$ \\
AWA12 & $\operatorname{IgM}(\lambda)$ & $1,063 \pm 102$ \\
WKG9 & $\operatorname{IgM}(\lambda)$ & $1,338 \pm 98$ \\
LAG9 & $\operatorname{IgM}(\lambda)$ & $1,248 \pm 181$ \\
GDC4 & $\operatorname{IgM}(\kappa)$ & $1,874 \pm 202$ \\
CNH11 & $\operatorname{IgM}(\kappa)$ & $1,694 \pm 91$ \\
CNH8 & $\operatorname{IgM}(\kappa)$ & $3,112 \pm 181$ \\
& &
\end{tabular}

* Determined by ELISA.

‡ Antibodies were tested by RIA at a concentration of $1.0 \mu \mathrm{g} / \mathrm{ml}$. Counts per minute (cpm) expressed as mean \pm SD. Tests were done in triplicate.

§See Methods.

The binding of antibodies to RIN 5F cells was also determined by radioimmunoassay (RIA). Glutaraldehyde-fixed RIN 5F cells in 96-well plates were washed twice with PBS and then incubated with $100 \mu \mathrm{l}$ of RPMI 1640 containing 10\% bovine serum albumin (BSA) for $1 \mathrm{~h}$ at $37^{\circ} \mathrm{C}$. After one wash with RPMI 1640 containing $1 \% \mathrm{BSA}, 50 \mu \mathrm{l}$ of the culture supernatant from EBV-transformed cells were added. After $1 \mathrm{~h}$ at $37^{\circ} \mathrm{C}$, the wells were washed twice, and $50 \mu \mathrm{l}$ of ${ }^{125} \mathrm{I}$-labeled goat antihuman IgM (Cappel Laboratories), containing $\sim 5 \times 10^{4} \mathrm{cpm}$, were added to each well. After $1 \mathrm{~h}$ at $37^{\circ} \mathrm{C}$, the supernatant was aspirated and the wells were washed three times. $100 \mu$ of $2 \mathrm{~N} \mathrm{NaOH}$ were added to each well, and the fluid and dissolved cells were absorbed by cotton swabs and counted in a Beckman $\mathbf{4 0 0 0}$ gamma counter (Beckman Instruments, Inc., Fullerton, CA).

Cloning. Lymphoblastoid cell cultures making antibodies to RIN 5F cells were cloned by limiting dilution ( 1 cell $/ 0.2 \mathrm{ml}$ per well) on feeder layers consisting of $10^{5}$ human allogeneic peripheral blood mononuclear cells treated with mitomycin $\mathrm{C}\left(25 \mu \mathrm{g} / \mathrm{ml}, 20 \mathrm{~min}, 37^{\circ} \mathrm{C}\right)$ in 96 -well tissue culture plates (18). Evidence that this procedure results in the production of monoclonal antibodies with multiple organ reactivity comes from earlier studies (12-14, 19-23) and from recent experiments in our laboratory showing that 10 different EBV-transformed cell lines cloned three times by the limiting dilution method retained the same multiple organ reactivity pattern as cells cloned only once (Casali et al., unpublished data).

Tissue preparation for immunohistochemistry. Tissues were obtained from human autopsy specimens. Saline perfusion was sometimes used to decrease extracellular immunoglobulins. Fresh tissues were snap-frozen in embedding medium (OCT; Miles Laboratories, Naperville, IL) by immersion in isopentane cooled with a dry ice-ethanol slurry. Frozen sections were cut at $6 \mu \mathrm{m}$, allowed to air dry for $5 \mathrm{~min}$, and then fixed for $5 \mathrm{~min}$ in acetone. In some cases sections were stored at $-40^{\circ} \mathrm{C}$.

Staining techniques. The reactivity of autoantibodies with tissues was determined by immunoperoxidase employing amplification with avidinbiotin complexes $(\mathrm{ABC})(24)$ or by indirect immunofluorescence.

\section{Results}

$E B V$-transformed $B$ lymphocytes make immunoglobulins that react with rat insulinoma (RIN $5 F$ ) cells. PBL were infected with EBV and cultured for three weeks in 96-well plates. All the microcultures showed lymphoblastoid cell transformation and immunoglobulin secretion, as in previous experiments (13). The supernatants of EBV-transformed B lymphocyte cultures were screened for both IgM and IgG antibodies reacting with fixed RIN 5F cells by ELISA. A total of 960 EBV-transformed B lymphocyte cultures were derived from PBL of 10 patients. Of these 960 cultures, $38(4 \%)$ were found to produce IgM antibodies that reacted with RIN 5 F cells. These cells were cloned by limiting dilution (18). In spite of the low cloning efficiency typical of EBV-transformed cells (13), six EBV-transformed B lymphocyte clones, derived from the PBL of five of the 10 patients and producing monoclonal antibody reactive with RIN $5 F$ cells, were isolated (Table I). The clones generally produced from 0.5 to $5.0 \mu \mathrm{g}$ of IgM per mililititer of culture medium.

Reactivity of monoclonal antibodies with RIN $5 F$ cells and human islets. Tables I and II show the reactivity of the six EBVtransformed cultures that were successfully cloned. All six human monoclonal antibodies were of the IgM class and bound by RIA to fixed RIN 5F cells (Table I). The binding was 5 to 15 times greater than with a nontissue reacting human monoclonal IgM. By indirect immunofluorescence (Fig. $1 \mathrm{~A}$ ), all six antibodies also strongly stained RIN 5F cells. Further studies showed that these monoclonals did not react with the surface of viable RIN 5 F cells as measured by RIA, immunofluorescence, or complement-dependent ${ }^{51} \mathrm{Cr}$-release assay (data not shown).

To see if the antibodies, positive on rat insulinoma cells,

Table II. Reactivity of EBV-induced Monoclonal Antibodies with Normal Human Tissues

\begin{tabular}{|c|c|c|c|c|c|c|c|}
\hline \multirow[b]{3}{*}{$\begin{array}{l}\text { Monoclonal } \\
\text { antibody }\end{array}$} & \multicolumn{7}{|l|}{ Reactivity* } \\
\hline & \multirow[b]{2}{*}{ Pancreas islets } & \multirow[b]{2}{*}{ Thyroid acinar } & \multirow[b]{2}{*}{$\begin{array}{l}\text { Peripheral nerve } \\
\text { axons }\end{array}$} & \multicolumn{3}{|c|}{ Stratified squamous epithelium (esophagus) } & \multirow[b]{2}{*}{ T lymphocytes } \\
\hline & & & & Basal & $\begin{array}{l}\text { Superficial } \\
\text { cellsł }\end{array}$ & Cell borders & \\
\hline AWA12 & + & + & + & - & + & - & - \\
\hline WKG9 & + & + & + & + & - & - & + \\
\hline LAG9 & + & + & + & + & + & + & - \\
\hline GDC4 & + & + & \pm & - & - & - & - \\
\hline CNH11 & + & + & - & - & - & - & - \\
\hline CNH8 & + & + & - & - & + & - & - \\
\hline
\end{tabular}

* Tested on frozen sections of normal human tissue by $\mathrm{ABC}$ immunoperoxidase and on smears of nylon wool-enriched human T lymphocytes $\left(\sim 95 \% \mathrm{OKT}^{+}\right.$cells) by ELISA and indirect immunofluorescence. + , positive reactivity; \pm , variable reactivity; - , negative reactivity. $\ddagger$ Includes both superficial and intermediate cells. 

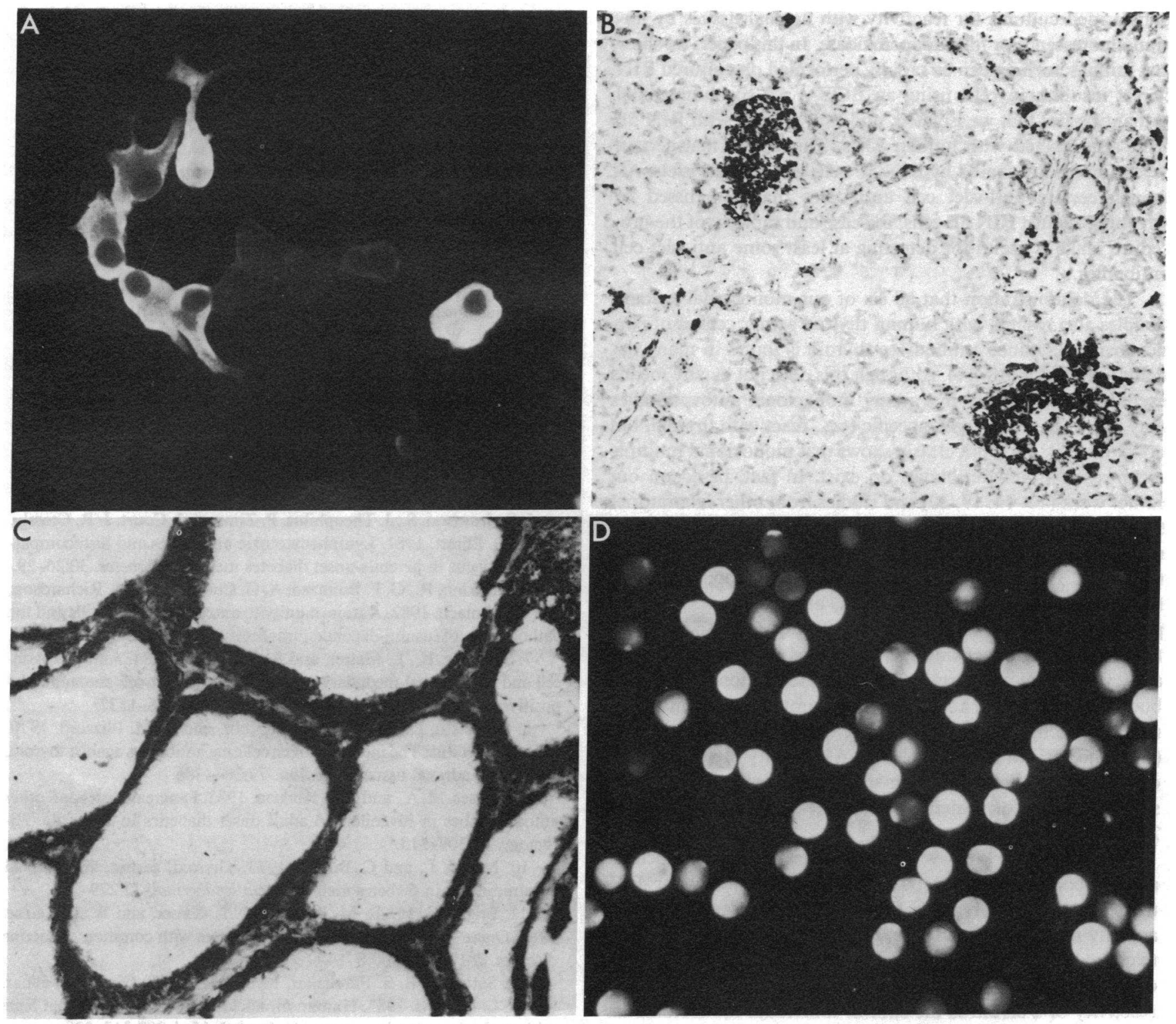

Figure 1. Reactivity of human monoclonal autoantibodies with rat and human tissues. $(A)$ Reactivity of monoclonal antibody WKG9 with glutaraldehyde-fixed rat insulinoma cells (RIN $5 F$ ) by indirect immunofluorescence $(\times 100)$. (B) Reactivity of monoclonal antibody CNH8 with islets of human pancreas (frozen section) by immunoper-

would also react with human islet cells, they were tested on normal human pancreas by immunoperoxidase or immunofluorescence (Fig. $1 B$ ). All six human monoclonal antibodies reacted with human islet cells (Table II).

Reactivity of the monoclonal antibodies with other human tissues. The six monoclonal autoantibodies also were tested for reactivity with other normal human tissues. As seen in Table II, each of the monoclonal autoantibodies also reacted with human thyroid acinar cells (Fig. $1 C$ ). In addition, each of the monoclonals showed a unique pattern of reactivity with other tissues. For example, monoclonal AWA12 reacted with peripheral nerves and superficial cells of the stratified squamous epithelium of the esophagus, but not with the cell borders or basal cells of the esophagus or with T lymphocytes. In contrast, WKG9 reacted

oxidase technique $(\times 25)$. $(C)$ Reactivity of monoclonal antibody LAG9 with acinar cells of human thyroid (frozen section) by immunoperoxidase technique $(\times 50)$. $(D)$ Reactivity of monoclonal antibody WKG9 with glutaraldehyde-fixed human $T$ cells by indirect immunofluorescence $(\times 100)$.

with esophageal basal cells and T lymphocytes (Fig. $1 D$ ), but not with the cell borders or superficial cells of the esophagus. LAG9 reacted with the basal cells, the superficial cells, and the cell borders of the stratified squamous epithelium of the esophagus, whereas GDC4 and CNH11 failed to react with these cells. Neither $\mathrm{CNH} 11$ nor $\mathrm{CNH} 8$ reacted with peripheral nerves.

\section{Discussion}

By transforming human peripheral blood lymphocytes with EBV, it is possible to prepare human monoclonal autoantibodies that react with human islets of Langerhans (13). One of the major hurdles in isolating these autoantibodies is the time and skill required to screen hundreds of supernatants from EBV- 
transformed cultures for reactivity with normal tissues by immunofluorescence or immunoperoxidase. In this paper, we show that initial screening can be rapidly performed on cultured RIN 5F rat insulinoma cells using an ELISA. All six monoclonal autoantibodies that we isolated, and that reacted with RIN 5F cells, also reacted with human islets. This shows that certain determinants are shared by RIN 5F cells and human islets. Although certain anti-islet cell antibodies may be missed by screening against RIN 5F cells, the ease and rapidity of the procedure make it useful for detecting at least some anti-islet cell antibodies.

The demonstration that all six of our monoclonal autoantibodies also reacted with human thyroid acinar cells is of particular interest since antibody to thyroid is found in many patients with IDDM (8-11). Although this does not by any means exclude the possibility that many monoclonal autoantibodies may be more or less organ-specific (e.g., react with thyroid, but not pancreas), our work clearly shows that monoclonal multiple organ-reactive autoantibodies do exist. In fact, based on our earlier work $(12-14,19,20)$ and studies from other laboratories (25-27), it appears that lymphocytes able to make multiple-organ reactive autoantibodies are very common in the normal B cell repertoire. For example, monoclonal autoantibodies, selected for their ability to react with DNA, also react with different polynucleotides and cardiolipin $(25,28)$; IgM monoclonal autoantibodies that react with IgG molecules also react with DNA and cytoskeletal elements (26) and a human monoclonal antibody that reacts with a 35,000 -mol wt protein common to thyroid, stomach, and pituitary also reacts with growth hormone (14). The basis of the multiple organ reactivity of at least some of these autoantibodies appears to be their capacity to recognize similar epitopes or proteins in different organs $(14,19,21-23$, 28-30).

We still do not know whether the reactivities of monoclonal autoantibodies, prepared by hybridoma technology or EBV transformation, are typical of the reactivities of autoantibodies actually found in human serum. Nonetheless, monoclonal autoantibodies are providing an approach for studying the reactivity of human serum by constructing its individual components. The reactivity of a serum is the sum of individual monoclonal antibodies, each of which, in isolation, would show a unique pattern of reactivity differing from that of the sum of the components. The observation that the serum of IDDM patients shows strong reactivity with islet cells, with descending reactivity to other organs (4-11), could be explained by the multiple organ-reactive character of the individual antibodies. For example, if all the antibodies shown in Table II were mixed together, they would show strong reactivity with the pancreas and thyroid, but, depending on concentration, little, if any, reactivity with $\mathrm{T}$ lymphocytes (unpublished data) or with the cell border of the esophagus. Thus, the apparent specificity of a mixture of monoclonal antibodies (e.g., a serum) would be determined by the most commonly expressed reactivities shared by the individual components. A similar proposal, concerning the common reactivities of different antibodies in a serum, was made by Talmage (31) in 1959 and amplified by Richards et al. $(32,33)$ in the mid 1970 s, before the development of monoclonal antibodies.

\section{Acknowledgments}

The authors acknowledge the National Diabetes Research Interchange for supplying human tissues and Dr. Kalman Salata and Dr. Bellur S.
Prabhakar for many helpful discussions. We also thank Mr. Joshua Scharff and Mr. Clifton Link for expert technical assistance, and Mrs. Eloise Mange for skillful secretarial work.

\section{References}

1. Herold, K. C., A. H.-J. Huen, A. H. Rubenstein, and A. Lernmark. 1984. Humoral abnormalities in type 1 (insulin-dependent) diabetes mellitus. In Immunology in Diabetes. D. Andreani, U. Di Mario, K. F. Federlin, and L. G. Heding, editors. Kimpton Medical Publishers, London. 105-122.

2. Bottazzo, G. F. 1984. $\beta$-cell damage in diabetic insulitis: are we approaching a solution? Diabetologia. 26:241-249.

3. Irvine, W. J. 1980. Autoimmunity and diabetes. In Autoimmune Aspects of Endocrine Disorders. A. Pinchera, D. Doniach, G. F. Fenzi, and L. Baschieri, editors. Academic Press, Inc., New York. 249-274.

4. Bottazzo, G. F., C. Vandelli, and R. Mirakian. 1980. The detection of autoantibodies to discrete endocrine cells in complex endocrine organs. In Autoimmune Aspects of Endocrine Disorders. A. Pinchera, D. Doniach, G. F. Fenzi, and L. Baschieri, editors. Academic Press, Inc., New York. 366-377.

5. Serjeantson, S., J. Theophilus, P. Zimmet, J. Court, J. R. Crossly, and R. B. Elliott. 1981. Lymphocytotoxic antibodies and histocompatibility antigens in juvenile-onset diabetes mellitus. Diabetes. 30:26-29.

6. Mirakian, R., G. F. Bottazzo, A. G. Cudworth, C. A. Richardson, and D. Doniach. 1982. Autoimmunity to anterior pituitary cells and the pathogenesis of insulin-dependent diabetes mellitus. Lancet. i:755-759.

7. Schopfer, K., L. Matter, and R. Tenschert. 1984. Anti-glucagoncell and anti-adrenal-medullary-cell antibodies in islet-cell-autoantibodypositive diabetic children. $N$. Engl. J. Med. 310:1536-1537.

8. Goldstein, D. E., A. Drash, J. Gibbs, and R. M. Blizzard. 1970. Diabetes mellitus: The incidence of circulating antibodies against thyroid, gastric and adrenal tissue. J. Pediatr. 77:304-306.

9. Menser, M. A., and J. R. Hudson. 1983. Pancreatic islet and other autoantibodies in juvenile and adult onset diabetics in Australia. $\mathrm{Pa}$ thology. 15:309-313.

10. Nerup, J., and C. Binder. 1973. Thyroid, gastric, and adrenal autoimmunity in diabetes mellitus. Acta Endocrinol. 72:279-286.

11. Bright, G. M., R. M. Blizzard, D. L. Kaiser, and W. L. Clarke. 1982. Organ-specific autoantibodies in children with common endocrine diseases. J. Pediatr. 100:8-14.

12. Satoh, J., B. S. Prabhakar, M. V. Haspel, F. Ginsberg-Fellner, and A. L. Notkins. 1983. Human monoclonal autoantibodies that react with multiple endocrine organs. N. Engl. J. Med. 309:217-220.

13. Garzelli, C., F. E. Taub, J. E. Scharff, B. S. Prabhakar, F. GinsbergFellner, and A. L. Notkins. 1984. Epstein-Barr virus-transformed lymphocytes produce monoclonal autoantibodies that react with antigens in multiple organs. J. Virol. 52:722-725.

14. Satoh, J., K. Essani, P. R. McClintock, and A. L. Notkins. 1984. Human multiple organ-reactive monoclonal autoantibody recognizes growth hormone and a 35,000-molecular weight protein. J. Clin. Invest. 74:1526-1531.

15. Miller, G., and M. Lipman. 1973. Release of infectious EpsteinBarr virus by transformed marmoset leukocytes. Proc. Natl. Acad. Sci. USA. 70:190-194.

16. Trizio, D., and G. Cudkowicz. 1974. Separation of T and B lymphocytes by nylon wool columns: evaluation of efficacy by functional assay in vivo. J. Immunol. 113:1093-1097.

17. Gazdar, A., W. Chick, H. Oie, H. Sims, H. King, G. Weir, and V. Lauris. 1980. Continuous clonal insulin and somatostatin secreting cell lines established from a transplantable rat islet cell tumor. Proc. Natl. Acad. Sci. USA. 77:3519-3523.

18. McKearn, T. J. 1980. Cloning of hybridoma cells by limiting dilution in fluid phase. In Monoclonal antibodies: hybridomas: a new dimension in biological analyses. R. H. Kennett, T. J. McKearn, and K. B. Bechtol, editors. Plenum Press, New York. 374.

19. Haspel, M. V., T. Onodera, B. S. Prabhakar, P. R. McClintock, 
K. Essani, U. R. Ray, S. Yagihashi, and A. L. Notkins. 1983. Multiple organ-reactive monoclonal autoantibodies. Nature (Lond.). 304:73-76.

20. Prabhakar, B. S., J. Saegusa, T. Onodera, and A. L. Notkins. 1984. Lymphocytes capable of making monoclonal autoantibodies that react with multiple organs are a common feature of the normal B cell repertoire. J. Immunol. 133:2815-2817.

21. Saegusa, J., T. Onodera, U. R. Ray, B. S. Prabhakar, and A. L. Notkins. 1985. Monoclonal autoantibodies that react with hormones also react with cells not containing those hormones. Endocrinology. 116 : 761-764.

22. Srinivasappa, J., J. Saegusa, B. S. Prabhakar, M. K. Gentry, M. J. Buchmeier, T. J. Wiktor, H. Koprowski, M. B. A. Oldstone, and A. L. Notkins. 1986. Molecular mimicry: Frequency of reactivity of monoclonal antiviral antibodies with normal tissues. J. Virol. 57:397401.

23. Notkins, A. L., and B. S. Prabhakar. 1986. Monoclonal autoantibodies that react with multiple organs: Basis for reactivity. Ann. $N Y$ Acad. Sci. In press.

24. Hsu, S. M., and E. Soban. 1982. Color modification of diaminobenzidine (DAB) precipitation by metallic ions and its application for double immunohistochemistry. J. Histochem. Cytochem. 30:1079-1082.

25. Lafer, E. M., J. Rauch, C. Andrzejewski, Jr., D. Mudd, B. Furie, B. Furie, R. S. Schwartz, and B. D. Stollar. 1981. Polyspecific monoclonal lupus autoantibodies reactive with both polynucleotides and phospholipids. J. Exp. Med. 153:897-909.

26. Rubin, R. L., R. S. Balderas, E. M. Tan, F. J. Dixon, and A. N.
Theofilopoulos. 1984. Multiple autoantigen binding capabilities of mouse monoclonal antibodies selected for rheumatoid factor activity. J. Exp. Med. 159:1429-1440.

27. Eisenbarth, G. S., A. Linnenbach, R. Jackson, R. Scearce, and C. M. Croce. 1982. Human hybridomas secreting anti-islet autoantibodies. Nature (Lond.). 300:264-267.

28. Shoenfeld, Y., J. Rauch, H. Massicotte, S. K. Datta, J. Andre'Schwartz, B. D. Stollar, and R. S. Schwartz. 1983. Polyspecificity of monoclonal lupus autoantibodies produced by human-human hybridomas. New. Engl. J. Med. 308:414-420.

29. Lane, D., and H. Koprowski. 1982. Molecular recognition and the future of monoclonal antibodies. Nature (Lond.). 296:200-202.

30. Essani, K., J. Satoh, B. S. Prabhakar, P. R. McClintock, and A. L. Notkins. 1985. Anti-idiotypic antibodies against a human multiple organ-reactive autoantibody: detection of idiotopes in normal individuals and patients with autoimmune diseases. J. Clin. Invest. 76:1649-1656.

31. Talmage, D. W. 1959. Immunological specificity. Unique combinations of selected natural globulins provide an alternative to the classical concept. Science (Wash. DC). 129:1643-1648.

32. Richards, F. F., and W. H. Konigsberg. 1973. Speculations: how specific are antibodies? Immunochemistry. 10:545-553.

33. Richards, F. F., W. H. Konigsberg, R. W. Rosenstein, and J. M. Varga. 1975. On the specificity of antibodies. Biochemical and biophysical evidence indicates the existence of polyfunctional antibody combining regions. Science (Wash. DC). 187:130-136. 